\title{
ЗООЛОГІЯ
}

УДК 574.583:59(285.33:477.81)

\section{ZOOPLANKTON OF WATERS OBJECTS WITHIN THE WETLAND OF RIVNENSKYI NATURE RESERVE}

\author{
K. Nazaruk ${ }^{1}$, R. Zhuravchak ${ }^{2}$ \\ ${ }^{1}$ Ivan Franko National University of Lviv \\ 4, Hrushevskyi St., Lviv 79005, Ukraine \\ e-mail: katja.nazaruk@gmail.com \\ ${ }^{2}$ Rivnenskyi Nature Reserve \\ Chudel village, Sarny district, Rivne region 34542, Ukraine \\ e-mail:rpz-10@ukr.net
}

\begin{abstract}
We examined features of zooplankton within wetlands of Rivnenskyi Nature Reserve. Totally we found 50 species of zooplankton. Among them the most dominated were cladocera -23 species ( $46 \%), 9$ species of copepods $(18 \%)$ and 8 species of rotifers $(16 \%)$. Most frequently occurred Chydorus latus Sars 1862 (frequency of occurrence of $80 \%$ ) and Chydorus sphaericus (O.F. Müller, 1785) (67 \%), also Pleuroxus trigonellus (O.F. Müller, 1776), Polyphemus pediculus (Linnaeus, 1761) Scapholeberis mucronata (O.F. Müller, 1776) (total 47 \%). Two species Chydorus ovalis Kurz, 1874 and Daphnia longispina (O. F. Mueller, 1785) dominated in number. The average value of Shannon index is $2,3 \pm 0,2$. We also presented ecological characteristics of these species. We didn't found the classic ratio between ecological forms of zooplankton, when phytophyl forms predominate over others, because of different types of researched waters. We determined that every researched water ecosystem has specific species composition of zooplankton.
\end{abstract}

Keywords: zooplankton, wetlands, marsh, Rivnenskyi Nature Reserve

Wetlands are one of the most vulnerable ecosystems on the Earth. There are some wetlands which need special efforts to preserve the natural regime of their functioning, and among them are marshes. ecosystems on the territory of Ukraine are very valuable from both nature protection and an environmental points of view. Most of them have been reclaimed primarily in Soviet times. An important function of as a contact link between small and large circulation of substances, is their gas-regulating function, which exceeds the similar function of forest ecosystems in the $7-15$ times.

It should be noted that are a refugia for the survival of not only many rare and endangered species of organisms, but also of whole groups and natural systems [12].

Rivnenskyi Nature Reserve is the largest nature reserve in Ukraine (total area is 47,046.8 ha). The territory of the reserve belongs to Volyn, or Western, Polissia. It reveals the main features of the landscape, which characterizes this part of Ukraine - the plainness of relief, the prevalence of sand, a positive balance of moisture, high level of forest cover and waterlogging [13].

\section{Materials and methods}

According to the physiographic and geobotanical zoning the territory of nature reserve belongs to the Volyn Polissia - a zone of mixed forests. It consists of four separated sections Biloozerske, Somyne, Syra Pohonya and Perebrody departments, which situated in different districts of Rivne region - Volodymyrets, Sarny, Rokytne and Dubrovytsia districts accordingly.

(C) Назарук К., Журавчак Р., 2017 
The territory of nature reserve has a high level of waterlogging (48\%), because it includes the largest peatlands of Ukraine and is represented by marshes of in Ukrainian Polissia all types. All departments of Rivnenskyi nature Reserve are included in the List of Wetlands of International Importance according to Ramsar Convention.

"Perebrody Peatlands" is one of the most preserved peatlands in the Ukrainian Polissia Region. It is a typical boreal wetland with different vegetation cover, including the largest non drained mire in Ukraine. In the northern part of the Site, an open-water eutrophic and meso-eutrophic peatland is situated with sedge-reed communities. Mesotrophic communities with sedgepeat moss predomine on the periphery of the site. "Perebrody Peatlands" is a unique type of wetlands in Ukraine and in Europe in general - with adjacent "Olmany Mires" on Belarus territory they form the biggest mire in Europe [9, 14].

The main territory of the "Somyne" site is a large sedge-sphagnum swamp area mostlywith mixed type of nutrition (transitive), which has the sparse growth of trees and forest. There is also a lake with a small number of eutrophic swamps, swamp of alder forests and pine forests are located. A large area of the transitional wetlands is preserved in its natural state. Here transitional marsh is interrupted zones of land and adjacent forest wetlands [10].

"Syra Pohonia Bog" is the only one marsh array in Ukraine with hilly morass natural system, which is typical for northern wetlands. The hills are covered mostly by oligotrophic pinecottongrass-sphagnum vegetation communities (with Eriophorum vaginatum, Sphagnum fuscum, Sph. magellanicum), while in watered depressions of treeless places occur sedge-sphagnum Cariceto (rostratae et limosae)-Sphagneta (cuspidati) and pod-grass-sphagnum (Scheuchzerieto (palustris)-Sphagneta) groupings dominate.The site includes a large and well protected marsh, which is mainly fed by rain and snow [11].

"Byle Lake and Koza-Berezyna Mire" includes a deep oligotrophic karst lake the Byle Lake and mire Koza Berezyna, the swamped forests and not swamped pine-woods between them. This bog was formed in a glacial valley with length of $17 \mathrm{~km}$ and width of $3 \mathrm{~km}$, where the glacial waters flow down. The mire is in good state, almost not damaged by land-reclamation. Here are represented all dominant vegetation communities of Polissian mire area [8].

Zooplankton samples for our research were taken in late May 2012 [5], in July and November 2013, in March and September 2014 [6] and in September and November 2015. Sampling and processing of materials we made according to the general methods [4]. We selected 15 localities for the research. They include the open waters of the marshes, small lentic roadside ditches and forest wetlands with stagnant weak stream water.

\section{Results and discussion}

We found 50 species of zooplankton in the studied of waters objects within the wetlands. Among them the most dominated were cladocera - 23 species (46\%), 9 species of copepods $(18 \%)$ and 8 species of rotifers (16\%). Most frequently occurred Chydorus latus Sars 1862 (frequency of occurrence of $80 \%$ ) and Chydorus sphaericus (O.F. Müller, 1785) (67\%), and also Pleuroxus trigonellus (O.F. Müller, 1776), Polyphemus pediculus (Linnaeus, 1761) Scapholeberis mucronata (O.F. Müller, 1776) (total 47 \%). Frequency of occurrence of the other species was much lower. The percentage of species that occurred only in one of the localities is $50 \%$. This indicates that each of marsh localities is unique.

Characteristics of species that occurred frequently: Ch. latus is a habitant of overgrown ponds, lakes and rivers. It can be founded in the slightly brackish waters with a $\mathrm{pH}$ of 4,5-7,5. Oligosaprobic species. Ch. sphaericus - everytopic species, which can live in the bush and in the pelagic zone, if there are algae. This species is extremely tolerant to water reaction. $\beta-\mathrm{o}-$ me- 
sosaprob. Pl. trigonellus is a habitant of puddles, marshes, ponds, lakes coasts and reservoirs it, is not found in acidic waters. It inhabits dense thickets of vegetation as good as the rocky bottom. $\beta$ - mesosaprob. S. mucronata can be founded on the coasts of lakes, reservoirs and ditches. It is a habitant of hyponeuston. Everyionic. $\beta$ - mesosaprob [3, 7].

However, these individuals of listed species are not numerous. The proportion of the total was less than $5 \%$.

The greatest number of zooplankton species (15) occurred in the water with light stream in the "Perebrody Peatlans", which is located among the marsh.

The number of zooplankton changed depending on the season during the year. Traditionally, the highest number of zooplankton was in the summer (9100 ind./ $\mathrm{m}^{3}$ ) (Fig. 1).

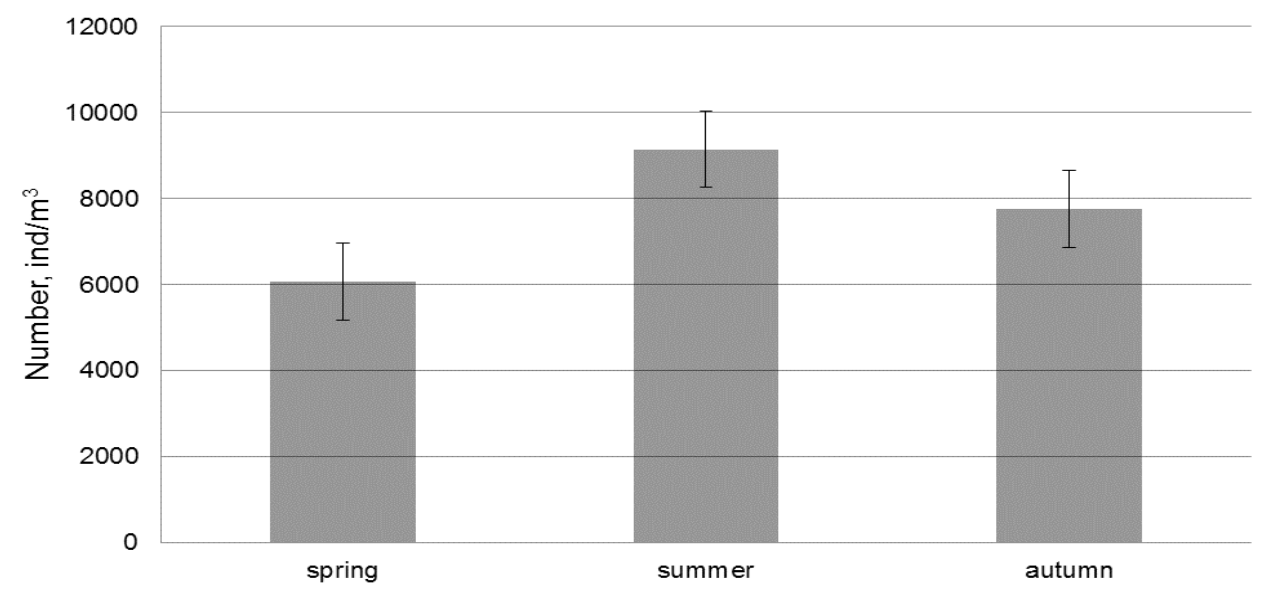

Fig. 1. Variable number of zooplankton during the year

Two species Chydorus ovalis Kurz, 1874 and Daphnia longispina (O. F. Mueller, 1785) dominated in number during the year. Their ratio was $13 \%$ of the total zooplankton. Ch. ovalis is the habitant of small water objects, or less peat waters. It prefers acidic waters. Oligosaprob. However, it should be noted that this species occurred in only one locality (in Biloozerske department, in small forest pond near the road), so it can characterize only this one locality.

D. longispina lives in different waters, but prefers acidic and slightly alkaline environments. It is a common zooplankton component of some brackish lakes, mass component of ponds and reservoirs. It can be used as an indicator of non acid conditions, but it can occur in acidic water with high content of humus. $\beta$ - mesosaprob $[3,7]$.

An average value of Shannon index is $2,3 \pm 0,2$. The index is high, because the number of species that occurred in the localities was small and their distribution in the water was more or less similar.

Thicket and phytophilous forms $(50 \%)$ dominant in the waters, but also a high ratio of planktonictes forms registered (Fig. 2). It is specific because these waters don't have large open stretches.

Primary and secondary filter-feeders dominate in the trophic structure of the zooplankton groups, but there are detritivore also.

Reservoirs were different, so classical interrelation, where phytophyl organisms should prevail in the swamps is not observed [1]. Also it concerns the food chains, because marsh waters are characterized by detrytic food chains [2]. 


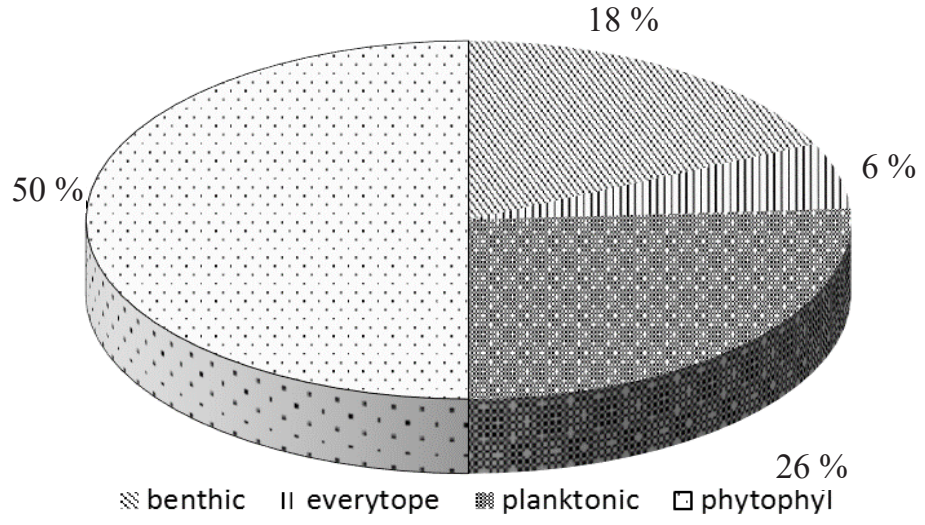

Fig. 2. Biotope classification of zooplankton in the marches

Marsh ecosystems, as a habitat, are characterized by specific factors according to which species composition of zooplankton distributes. Every researched water ecosystem has specific species composition of zooplankton, which is inherent only to it.

\section{REFERENCES}

1. Andronykova I. N. Main Results of the study cladocera humified reservoirs // Modern problems of studying Cladocera. SPb.: Gidrometeoizdat, 1992. P. 81-99. (In Russian).

2. Cherevichko A. V. Zooplankton formation regularities in upper-bog reservoirs (with the Polistovo-Lovatskaya upper-bog system as an example) // Povolzhskiy Journal of Ecology. 2011. N 4. P. 542-548. (In Russian).

3. Manuilova E. F. Cladocera fauna of the USSR. M.: Nauka, 1964. 235 p. (In Russian).

4. Methodical recommendations for the selection, processing and evaluation of hydrobiological samples to determine the quality of the water: for students of 3-5 courses of the Faculty of Biology. Lvov: LGU, 1990. 59 p. (In Russian).

5. Nazaruk K. M., Zhuravchak R. O., Khamar I. S. Concerning zooplankton water bodies Rivne Nature Reserve // State and biodiversity ecosystems Shatsk National Park (Shatsk, 2012). Lviv, 2012. P. 51-52. (In Ukrainian).

6. Nazaruk K., Zhuravchak R. Zooplankton of water bodies of Rivnenskiy Nature Reserve // Visnyk of the Lviv University. Series Biology. 2015. Issue 69. P. 220-226. (In Ukrainian).

7. Oleksiv T. I. Indicators of quality of natural waters from an environmental position. Lviv: Svit, 1992. 235 p. (In Russian).

8. Ukraine. Byle Lake and Koza Berezyna Mire [Electronic resource] // Ramsar Sites Information Service. Created by RSIS V.1.7 on - 25 January 2017. Source access: https://rsis.ramsar. org/RISapp/files/RISrep/UA2281RIS_1701_en.pdf.

9. Ukraine. Perebrody Peatlands [Electronic resource] // Ramsar Sites Information Service. Created by RSIS V.1.6 on - 8 November 2016. Source access: https://rsis.ramsar.org/RISapp/ files/RISrep/UA1402RIS_1611_en.pdf.

10. Ukraine. Somyne Swamps [Electronic resource] // Ramsar Sites Information Service. Created by RSIS V.1.7 on - 13 December 2016. Source access: https://rsis.ramsar.org/RISapp/ files/RISrep/UA2275RIS_1612_en.pdf.

11. Ukraine. Syra Pogonia Bog [Electronic resource] // Ramsar Sites Information Service. Created by RSIS V.1.7 on - 13 December 2016. Source access: https://rsis.ramsar.org/RISapp/ files/RISrep/UA2274RIS_1612_en.pdf. 
12. Wetland ecosystems of Eastern Carpathians in Ukraine / Kovalchuk A. A., Felbaba-Klushyna L. M., Kovalchuk N. at al. // Under the editorship A. A. Kovalchuk. Uzhgorod: Lira, 2006. 228 p. (In Ukrainian).

13. Wetlands Ukraine: a handbook / ed. G. B. Marushevsky, I. S. Zharuk. K.: Wetlands International Black Sea Programme, 2006. 312 p. (In Ukrainian).

14. Zhuravchak R. O., Yakushanko D. M., Golovko O. V., Martyniuk V. O. Wetland of International Importance "Perebrody Peatlands" // Monitoring of Wetland of International Importance. Methods and results (Proceedings of seminar "Organization and results of monitoring of Wetland of International Importance in Ukraine”. Odessa, March 4-6, 2014). K.: DIA, 2014. P. 67-72. (In Ukrainian).

Стаття: надійшла до редакції 02.03.17

доопращьована 29.06.17

прийнята до друку 30.06.17

\title{
ЗООПЛАНКТОН ВОДНИХ ОБ'ЄКТІВ БОЛІТ РІВНЕНСЬКОГО ПРИРОДНОГО ЗАПОВІДНИКА
}

\author{
К. Назарук ${ }^{1}$, Р. Журавчак ${ }^{2}$ \\ ${ }^{1}$ Львівський національний університет імені Івана Франка \\ вул. Грушевського, 4, Львів 79005, Україна \\ e-mail: katja.nazaruk@gmail.com \\ ${ }^{2}$ Рівненський природний заповідник \\ урочище "Дубки", с. Чудель, Сарненський р-н, Рівненська обл. 34542, Украӥна \\ e-mail:rpz-10@ukr.net
}

Розглянуто особливості зоопланктону водних об’єктів боліт Рівненського природного заповідника. Загалом відзначено 50 видів зоопланктерів, серед яких було 23 види (46\%) гіллястовусих рачків, 9 видів (18\%) веслоногих рачків і 8 видів (16\%) коловерток. Встановлено види, що трапляються найчастіше: Chydorus latus Sars 1862 (частота трапляння 80 \%) та Chydorus sphaericus (O.F. Müller 1785) (67\%), а також Pleuroxus trigonellus (O. F. Müller, 1776), Polyphemus pediculus (Linnaeus, 1761), Scapholeberis mucronata (O. F. Müller, 1776) (47 \%). Переважаючими за чисельністю були два види - Chydorus ovalis Kurz, 1874 та Daphnia longispina (O. F. Müller, 1785). Обчислено індекс Шеннона 2,3 $\pm 0,2$. Наведено екологічну характеристику цих видів. Класичного співвідношення, коли фітофільні форми переважають над іншими, не виявлено, оскільки досліджувані водойми були різнотиповими. Встановлено, що кожна досліджувана водойма боліт Рівненського природного заповідника має специфічний видовий склад зоопланктерів, притаманний тільки їй.

Ключові слова: зоопланктон, водно-болотні угіддя, болото, Рівненський природний заповідник 